\title{
Landlocked Countries:
}

\section{A Way to Integrate with Coastal Economies}

\author{
Bidisha Lahiri \\ Oklahoma State University
}

Feroz K. Masjidi

Oklahoma State University

\begin{abstract}
We consider some of the important economic constraints faced by landlocked economies in a game theoretic framework that involves its neighbor that has access to the ocean. We identify the strengths that the landlocked economy might have or develop through policy in order to negotiate with its neighbor. The model is an infinitely repeated game between two asymmetric economies, with the threat of reversion to Nash equilibrium if an economy deviates from the cooperative agreement. We find that sustainable cooperative equilibriums that are Pareto superior do exist, drawing attention to the benefits of economic cooperation between neighbors even if they differ on geographical, political, or diplomatic issues. We do several robustness checks that further bring out the constraints and policy implications for the landlocked economies.
\end{abstract}

JEL Classifications: F51, F53, F55, F59

Key Words: Landlocked Economies, Coastal Economies, Bilateral Negotiation, Self-Sustaining Cooperation, Transit, Foreign Input

\footnotetext{
* Corresponding Author: Bidisha Lahiri; 329 Business Building, Department of Economics, Spears School of Business, Oklahoma State University, Stillwater, OK 74078, Tel: 405 744-7530, E-mail: bidisha.lahiri@okstate.edu.

Co-Author: Feroz K. Masjidi; Department of Economics, Spears School of Business, Okahoma State University, Stillwater, OK 74078, Email: masjidi@ostatemail.okstate.edu.
} 


\section{Introduction}

While approximately $20 \%$ of the countries in the world are landlocked, they are distributed as approximately $40 \%$ of the world's low income economies and less than $10 \%$ in the world's high income countries. ${ }^{1}$ These statistics highlight that there exist economic problems unique to landlocked economies and that the number of such countries is large enough to command important consideration in the economic literature. The landlocked countries are often surrounded by coastal economies that differ with respect to diplomatic, geographic, and socio-economic aspects. Our model incorporates some of these differences and explores whether the unilateral policy choices of these two types of countries might be altered, through bilateral cooperation, in a manner that benefits both the landlocked and coastal economies.

High transportation costs to access the ocean through the neighboring countries raise trade costs and costs of building domestic infrastructure for the landlocked countries. The landlocked countries have to pay higher prices on imports and part of the export revenue as rents to these neighboring countries for having to use the territory of the coastal economy for transit of goods. In addition to creating trade obstacles and less-developed infrastructure, the landlocked economies are left vulnerable even with respect to basic necessities like food. Political disruptions or other diplomatic reasons sometimes result in the coastal economy blocking the transit of food and other material to its landlocked neighbor. Diversification of the transit options to several neighbors of the landlocked economies could potentially reduce the monopoly power of any single coastal neighbor. The landlocked economies also might develop themselves into transit corridors to provide a shorter and less expensive route for one neighbor to access the market of another neighbor. However, these strengths would be severely limited or nonexistent if a landlocked economy is encompassed on all sides by very few or only a single neighbor. Additionally many of the landlocked countries are resource-rich though most of them have poorly developed domestic industries. Policies aimed at developing industries within the landlocked economy in which the coastal neighbors also have a stake may improve the possibility of regional cooperation.

The recent incident of Pakistan closing its borders to NATO supplies to Afghanistan remains fresh in the minds of most people. This incident makes it appear that a landlocked country is at the mercy of its coastal neighbour. However, a less reported but very important fact remains that China has been forging economic relations with Afghanistan as the Chinese government has launched a sustained campaign to develop the region's transportation and other commercial infrastructure ${ }^{2,3}$ with the largest single foreign investment project in Afghanistan

\footnotetext{
The percentages are approximate indicators as the numbers vary by the political definitions of independent states and economies.

${ }^{2}$ Weitz, R. "Afghanistan in China's Emerging Eurasian Transport Corridor," The Jamestown Foundation China Brief, Vol. 10 (14) (http://www.jamestown.org/single/?no_cache=1\&tx_ttnews[tt_news]=36604).

Kuhn, A. “China Becomes A Player In Afghanistan's Future,” National Public Radio (http://www.npr.org/templates/story/story.
} 
coming from China. This shows that the underlying bargaining powers of a landlocked economy may not be clearly evident without coordinated research. Additionally the government of Afghanistan is also working with its neighbors to build railway lines that would support the main regional transit routes linking Iran and Pakistan with Central Asia as well as connecting Afghanistan's rail system with that of China's through Tajikistan. This underscores that the landlocked economy might undertake domestic policy to develop its infrastructure and industries to make itself more attractive as a transit route and a trade partner.

The relationship between India and Nepal is another example of such obscure opportunities with the general consensus being that India has a monopoly of power over the economy of $\mathrm{Ne}$ pal. However, Nepal undertook a series of policies including "Exporters' Exchange Entitlement Scheme" aimed at reducing its dependence on India such that in 1988, official statistics showed that India was receiving only 38 percent of Nepal's total exports and supplying only 30 percent of Nepal's total imports.

Africa is comprised of 15 landlocked countries: Botswana, Burkina Faso, Burundi, Chad, Central African Republic, Ethiopia, Lesotho, Malawi, Mali, the Niger, Rwanda, Swaziland, Uganda, Zambia, and Zimbabwe. However, many of these countries have developed their infrastructure to serve as transit corridors ${ }^{6}$ between two neighbors which provide them power to bargain for concessions on other dimensions.

Most of the international agreements, on the other hand, focus solely on improving and simplifying the transit issues. ${ }^{7,8,9}$ Our model points to the fact that imbalance in transit power may be balanced off against distortions in other markets. For example, Borchert et. al. find that in an attempt to prevent the entry of coastal firms and input into the domestic industry, the landlocked economies of Laos, Nepal, and Zambia implement unilateral policies that are inefficient for the domestic economy. ${ }^{10}$

Our model invites countries to undertake a broader policy approach that links across different issues to explore, for instance, whether international cooperation regarding transit issues might be rewarded with cooperation on the domestic industry.

\footnotetext{
php?storyId=113967842).

${ }^{4}$ British Broadcasting Corporation News Asia. "Afghan railway: First train runs on new line in north” (http://www.bbc.co.uk/news/ world-asia-16287929).

${ }^{5}$ Whelpton, J. “A History of Nepal” by Cambridge University Press, pp: 151-152.

${ }^{6}$ United Nations Economic Commission for Africa (http://new.uneca.org/Portals/aria/aria4/chap7.pdf).

${ }^{7}$ United Nations Almaty Programme of Action (http://www.un.org/special-rep/ohrlls/lldc/Almaty_PoA.pdf).

${ }^{8}$ "Transit Transport Issues in Landlocked and Transit Developing Countries," United Nations Economic And Social Commission For Asia And The Pacific (http://siteresources.worldbank.org/INTRANETTRADE/Resources/WBI-Training/UN-Landlocked.pdf).

${ }^{9}$ "Regional cooperation in transit transport: Solutions for landlocked and transit developing countries," United Nations Conference on Trade and Development ( http://unctad.org/en/docs/c3em30d2_en.pdf).

${ }^{10}$ Borchert, I., Gootiiz, B., Grover, A., and Mattoo, A. "Landlocked or Policy Locked? How Services Trade Protection Deepens Economic Isolation,” World Bank Policy Research Working Paper 5942 (http://www-wds.worldbank.org/servlet/WDSContentServer/ WDSP/IB/2012/01/10/000158349_20120110105432/Rendered/PDF/WPS5942.pdf).
} 
In this paper we will develop an analytical model of bilateral cooperation between a landlocked economy and its coastal neighbor, with or without the presence of other neighbors. We capture the unique strengths and dependencies of these two types of countries and investigate if there exist possibilities of self-sustaining cooperative equilibriums that are Pareto superior for both economies. To our knowledge, ours is the first paper to analytically capture the strategies available to both types of countries and explore the possibility of change of policies in an attempt to explicitly investigate mutual welfare gains from cooperation. Bilateral negotiations are modeled as a process of Nash bargaining over the set of self-enforcing domestic policy configurations. We identify self-sustaining cooperative policies by using the structure of infinitely repeated game with the threat of reversion to noncooperative Nash equilibrium if an economy deviates from the cooperative agreement.

\section{Literature Review}

The existence of several policy papers focusing on specific case studies point to the importance of the economic problems of the landlocked economies ${ }^{11,12}$ and there are several empirical papers that analyze the magnitude of the effects of being landlocked.

One of the earlier papers is by Jayaraman and Shrestha (1976) who look into problems and possible solutions for the landlocked country of Nepal whose access to the ocean for trade purposes is dependent on its neighbor India. Nepal's bargaining power is severely limited due to weak domestic industries to which the authors suggest improvement and diversification of its these industries to improve Nepal's welfare.

Geographers like Debrie and Steck (2001) claim that throughout history a country can be viewed as having an advantage due to being a centrally located country if it provides direct and cheaper transit routes between different countries, though with the improvement in the shipping industry, the same country can be viewed as a disadvantaged landlocked economy albeit the geographic characteristics do not change.

MacKellar et al. (2000) analyze the impact of being landlocked on economic growth. Using data from 92 low-income and middle-income countries over the period between 1960 and 1992, they estimate that landlocked economies have a $1.5 \%$ lower growth rate. They advocate for the development of alternative transportation routes, industries that do not require physical transport, and regional trade arrangements.

\footnotetext{
${ }^{11}$ Economic and Social Commission for Asia and The Pacific ( ESCAP), 1997, Issues and problems of the landlocked countries and Modalities for addressing them, Bangkok, note by the secretariat.

${ }^{12}$ Ahmed, S. and Ghani, E. 2008. "Making Regional Cooperation work for South Asia's Poor," Policy Research Working Paper Series 4736, The World Bank.
} 
An empirical analysis by Raballand (2003) measures the impact of being landlocked on trade using four measures of being landlocked: the first estimation is obtained by using a dummy variable, the second estimates the shortest distance between a landlocked country and the nearest main port facility, the third one shows the number of borders of coastal countries, and the fourth considers the number of national borders. The study finds that being landlocked will decrease trade by almost $80 \%$ when it is measured by a dummy variable. They demonstrate that effect is closely linked to geographical location distance from major markets, main trade flows, and main hub (airports or ports) facilities measured by additional transport cost and the number of border crossing. Arvis et al. (2010) further estimate that landlocked economies face a cost penalty ranging from 8 to 250 percent and a time penalty ranging from 9 to 130 percent for using the coastal neighbor as a transit corridor. Radelet and Sachs (1998) also study the transport costs issues using CIF and FOB data from IMF for 97 developing countries, 17 of which are landlocked and estimate that transport and insurance costs are twice as high for landlocked countries compared to coastal countries.

Faye et al. (2004) look into the problem of infrastructure and dependence of a landlocked country on transit neighbors. They argue that there are four main aspects of a landlocked country's dependence on a transit neighbor: dependence on neighbors' infrastructure; dependence on sound cross-border political relations; dependence on neighbors' peace and stability; and dependence on neighbors' administrative practices. Analyzing these dimensions, their policy suggestions for a landlocked country are developing their local transportation infrastructure, having regional infrastructure integration strategies, and focusing on administration coordination in the regional integration strategies. They also suggest that landlocked countries should invest in developing industries which are less affected by transport cost. De (2006) estimates a structural model to assess the impact of infrastructure and transaction costs on the bilateral trade of selected Asian economies. He finds that transaction costs are a statistically significant and important determinant in explaining variation in trade, with the median landlocked country having transport costs which are 55 percent higher than the median coastal economy. This puts the landlocked economies at a major disadvantage in international trade compared to the coastal economies. On similar lines, Grigoriou (2007) finds that improvement in the infrastructure of the transit country would increase the international trade of the landlocked country by $52 \%$. The three main policy implications emerging from this paper are improving the infrastructure, managing the transit corridors as regional public goods through international cooperation, and establishing alternate transit routes to reduce the monopoly power of any given coastal economy to improve the trade outcomes for landlocked economies. Shrestha and Upadhyay (2004) extend the standard gravity model to evaluate the role of noneconomic factors such as political cooperation, cultural similarity and geography, including the landlocked characteristic, on bilateral trade.

Lastly, the paper by Shrestha and Heffley (2003) is a theoretical paper that comes closest to our approach. They compare the implications for labor market outcomes in two economies 
that are structurally different: one that has access to the port of export and the other that does not. They define autarky as labor being internationally immobile and regional integration as labor being perfectly mobile internationally, and find that welfare improves with integration. This is static model that does not question whether the integration is sustainable or not. We add the economic sustainability component through the consideration of incentive-compatible cooperative equilibria in a repeated game setting. Additionally by focusing only on labor markets as the characterization of regional integration, they ignore the multiple other dimensions that characterize the international relation between a landlocked and a coastal economy as identified in the literature above. In contrast, our paper incorporates the other dimensions and examines how gains in one dimension may be traded off for losses in some other dimension to arrive at a sustainable cooperation.

\section{Theoretical Model}

Our model looks at the interaction between two economies with or without the presence of other neighbors. Based on real-world situations, we assume several structural differences between these two economies, the most important among them being that one, denoted henceforth as Country A, as having access to the ocean and hence access to rest of the world for trade purposes, while the other landlocked economy, denoted henceforth as Country B, having to pay a rent to its neighbor to access the ocean. The other difference incorporated is that the landlocked Country B might offer itself as a transit corridor if the cost of a shorter land route through its territory is cheaper than a longer water router. Thirdly, the dependence of Country B on its neighbor, in addition to trade purposes, is usually also for input to be employed in its domestic industry. These are the major facets defining the international relation between a landlocked economy and its coastal neighbor(s) and will show up in the definition of the welfare function for each of these two economies.

The model initially starts with a unilateral decision made by each country. The coastal economy A will decide the rent to charge its landlocked neighbor for accessing the ocean, while the landlocked economy B will decide how much of the foreign input to use for its domestic industry and also if it can provide a cheaper and direct land route to the coastal economy to access other landlocked or coastal economies in the region. Afterwards we will examine whether there exists a possibility for bilateral cooperation where by moving away from the unilateral policy choices, the gains in one market can outweigh the losses in another market such that the aggregate welfare of each economy is higher under cooperation. After establishing the condition for existence for such equilibrium, we will restrict out attention to the set of sustainable cooperation using a framework of infinitely repeated game where any deviation by a country is met by punishment in the form of reversion to noncooperative Nash equilbria for all future periods. 
Let us begin by identifying the policy choices for each country in our model. If $P_{\boldsymbol{O}}$ be the fixed world prices for the net imports demanded by Country B, and if Country A decides to charge a rent $(R)$ for access to the ocean, ${ }^{13}$ then the price $\left(P_{X}\right)$ denoting the effective price paid by $\mathrm{B}$ for its imports is given by $P_{X}=R * P_{O}$. Since $P_{O}$ is assumed to be constant, $P_{X}$ can equivalently be used as the indicator for the policy choice for Country A. We assume a linear demand $\left(\alpha-\beta P_{X}\right)$ for imports by Country $\mathrm{B}$, while Country A chooses $P_{X}$ to maximize its rental income.

Country $\mathrm{B}$ has a domestic industry captured by a linear production function, $\mathrm{Y}=\gamma L_{A}$, where $\mathrm{L}_{\mathrm{A}}$ is the employment of foreign input and $\gamma$ is a parameter that captures the size, productivity, and employment of domestic input. ${ }^{14}$ Under the more general assumption of imperfect elasticity of foreign input, Country B acts a monopsonist with respect to the employment of foreign input. ${ }^{15}$ Given that there is typically cost of international mobility of labor, Country B will have to pay higher wages to attract more input from Country A. We assume that the inverse supply function of input from A to B is given by $W=m+n L_{A}$. Under noncooperation, Country B will choose $L_{A}$ to maximize the profits in the domestic industry given by $P_{Y} \gamma L_{A}-L_{A}\left(m+n L_{A}\right)$ with $P_{Y}$ being the market price of the commodity produced domestically by Country B. ${ }^{16}$

The other dimension to economy $\mathrm{B}$ is that while being landlocked, it might be able to exploit its advantage of being centrally located by offering potential land routes (or transit corridors) that are shorter and cheaper than ocean routes to access other economies in that region. If Country B has other neighbors $(N)$ besides Country A and the cost to Country A of accessing each of these countries for trade purposes via the ocean route is $C,{ }^{17}$ then country B can offer land-route alternatives at a cost marginally lower than $C$ and attract transit through its own territory. When setting policies unilaterally, Country B will extract maximum rent $N^{*} C$ on the land routes equal to the opportunity cost of the ocean routes. However, if Country B is surrounded on all sides by the single neighbor A, then $N=0$ and this aspect vanish.

Countries that are hostile to their neighboring countries tend to adopt a hostile stance in all their policy choices regarding their neighbors while economies that have a friendly relationship with their neighbors tend to provide concessions regarding most policy variables affecting the

\footnotetext{
${ }^{13}$ This is also equivalent to transit obstruction caused by country A that has an opportunity cost of $R$ to country $\mathrm{B}$.

${ }^{14}$ Foreign input such as foreign capital or skilled labor are complements to the domestic input.

${ }^{15}$ Country B is technically a monopsonist with respect to the residual supply of input from Country A, i.e. the amount of input of Country A that Country B attracts away from Economy A.

${ }^{16}$ It is empirically established that exports typically face less transit obstruction than import commodities. One economic reason for this is that if Country A obstructs the entry of foreign imports into Country B then it can actually sell goods produced within Country A in the market of Country B, while such an incentive is missing in the case of export goods. Based on this empirical observation, to maintain greater transparency of the model, we consider transit obstruction with respect to import commodities but not with respect to export commodities. Incorporating transit obstruction in both markets does not add significant contribution to the model.

${ }^{7}$ If there are countries in the region that are double landlocked and the only access to them is through Country B, then the alternate sea route does not exist and hence $\mathrm{C}$ is extremely high, i.e. Country B can extract high rent for offering entry to those regions. Alternately, if the cost of ocean routes is relatively cheap, and the cost of offering alternate land routes is greater, then Country B cannot offer these alternate land routes as economically attractive options.
} 
neighbors. This is captured by the variable $T \in[0,1]$ that indicates the degree of cooperation practiced by Country B both with respect to allowing the use of its transit corridor and the employment of foreign input. Hence, a higher $T$ means a high degree of cooperative stance taken by the landlocked economy toward the coastal economy. This translates into lower payments charged for allowing the use of transit corridors through the landlocked economy to other countries of the region and higher employment of coastal economy input in the domestic industry of a landlocked economy. Lower $T$ has the opposite implications regarding both transit corridors and the use of coastal input. This is our innovation in this paper to reduce the policy parameters of the model without losing any significant insight.

At the extreme, $T=0$ signifies zero cooperation and corresponds to unilateral profit maximization by country B. $T=1$ signifies maximum possible cooperation and corresponds to zero profit for Country B. The actual level of cooperation that is optimum and sustainable will be determined by our framework of infinitely repeated games.

Based on the model specification above, we define the welfare functions of the two countries in Equations 1 and 2.

$$
W_{A}\left(P_{X}, T\right)=P_{X}\left(\alpha-\beta P_{X}\right)-N * C(1-T)+\left[L_{A} *(1+T)\left\{m+n L_{A}^{*}(1+T)\right\}\right]
$$

The first term on the right-hand side of the welfare function of Country $\mathrm{A}$ is the transit revenue collected for providing Country $B$ access to the ocean for its import needs. The second term is the payment extracted by Country B from A for use of land routes for accessing other economies in the region as a cheaper alternative to ocean access. The third term is the income of input owned by Country A and employed in Country B.

$$
\left.W_{B}\left(P_{X}, T\right)=\left(\alpha-\beta P_{X}\right)^{2}\right) / 2 \beta+N * C(1-T)+\left[L_{A}^{*}(1+T)\left\{P_{Y} \gamma-m-n L_{A}^{*}(1+T)\right\}\right]
$$

The first term of the right-hand side of Equation 2 is the consumer surplus in Country B from consuming imports at price $P x$. The second term is the payment extracted by Country B from A for use of alternate land routes for accessing other economies in the region. The third term is the profit in the domestic industry of Country B after subtracting the payments made on foreign owned input. As $T$ goes up, the payment demanded for the alternate land routes goes down while the employment of foreign input goes up and domestic profits go down. This is an adjustment that Country B might be willing to consider in exchange for Country A lowering the $P x$ representing the barrier to ocean access.

Under unilateral noncooperative decision-making, each economy will set its policy to maximize domestic welfare, taking the other economy's policies as given. 


$$
\begin{aligned}
& P_{X}^{N}=\operatorname{argmax}_{\mathrm{PX}} \Longrightarrow W_{A}\left(P_{X}, T\right) P_{X}^{N}=\frac{\alpha}{2 \beta} \\
& T^{N}=\operatorname{argmax}_{\mathrm{T} \in[0,1]} W_{B}\left(P_{X}, \mathrm{~T}\right) \Longrightarrow T^{N}=0
\end{aligned}
$$

Hence, the country with the ocean access will set the obstruction similar to the monopolist price setting while the landlocked country will, unilaterally, have no incentive for offering any concessions to its coastal neighbor.

The iso-welfare loci of the two countries are represented in the two panels of Diagram 1. Both are negatively sloped in the policy choice space as shown in Equations 5 and 6.

Let's start by exploring the iso-welfare locus for the coastal economy A.

$$
d\left(W_{A}\right)=\left[-(N * C)-L_{A}^{*}\left(m+2 n L_{A}^{*}(1+\mathrm{T})\right)\right] d T-\left[\left(\alpha-2 \beta P_{X}\right)\right] d P_{X}
$$

We know from profit maximizing in the domestic industry that $\alpha-2 \beta P_{X}=0$ for noncooperative price setting. If $P_{X}<P_{X}^{N}$ due to cooperation, $\alpha-2 \beta P_{X}>0$. Hence along the iso-welfare functions of the coastal economy A:

$$
\left.\frac{d P_{X}}{d T}\right|_{d\left(W_{A}\right)=0}=\frac{-(N * C)-L_{A}^{*}\left(m+2 n L_{A}^{*}(1+T)\right)}{\left(\alpha-2 \beta P_{X}\right)}<0
$$

Similarly for Country B:

$$
d\left(W_{B}\right)=\left[-(N * C)-L_{A}^{*}\left(P_{Y} \gamma-2 n L_{A}^{*}(1+\mathrm{T})\right)\right] d T-\left[\left(\alpha-\beta P_{X}\right)\right] d P_{X}
$$

We know from profit-maximizing in the domestic industry that $P_{Y} \gamma-\left(m+2 n L_{A}^{*}(1+\mathrm{T})\right)=$ 0 for $\mathrm{T}=0$. If $\mathrm{T}>0$ due to cooperation, $P_{Y} \gamma-\left(m+2 n L_{A}^{*}(1+\mathrm{T})\right)<0$. Hence along the iso-welfare functions of the landlocked economy $\mathrm{B}$ :

$$
\left.\frac{d P_{X}}{d T}\right|_{d\left(W_{B}\right)=0}=\frac{-(N * C)+L_{A}^{*}\left(P_{Y} \gamma-\left(m+2 n L_{A}^{*}(1+T)\right)\right.}{\left(\alpha-\beta P_{X}\right)}<0
$$

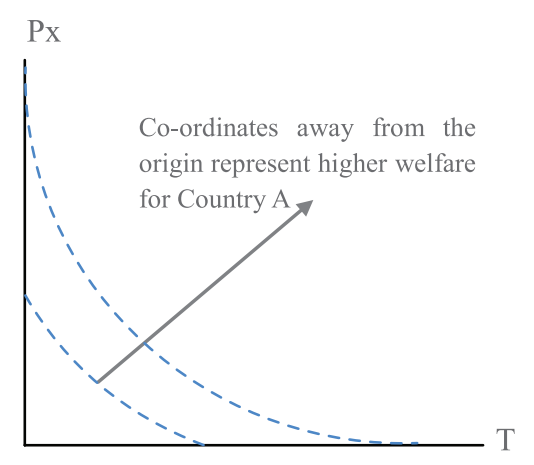

Figure 1A. Iso-welfare loci for Economy A

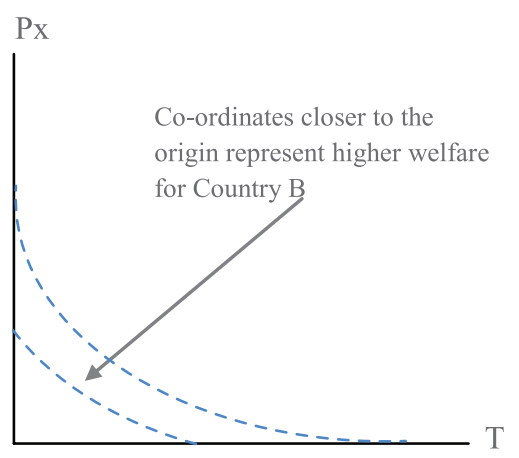

Figure 1B. Iso-welfare loci for Economy B 
For Country A, a larger T improves welfare while a smaller Px lowers welfare to offset each other to remain on an iso-welfare locus. The opposite applies to Country B. However, for Country A, the loci that are away from the origin represent higher welfare levels for the economy while for Country B, the loci that are closer to the origin represent higher welfare. This implies that with cooperation, Country A will try to attain a locus that is to the right of its noncooperative iso-welfare loci while Country B will try to move to one that is closer to the origin. Hence for a necessary condition for a cooperative equilibrium to exist, the iso-welfare loci for Country B should be flatter than the iso-welfare loci of country A as shown in Diagram 2. By comparing Equations 5 and 6, we find that the necessary condition is satisfied as shown in Equation 7 below.

$$
\left.\left|\frac{d P_{X}}{d T}\right|_{d\left(W_{A}\right)=0}|>| \frac{d P_{X}}{d T}\right|_{d\left(W_{B}\right)=0} \mid
$$

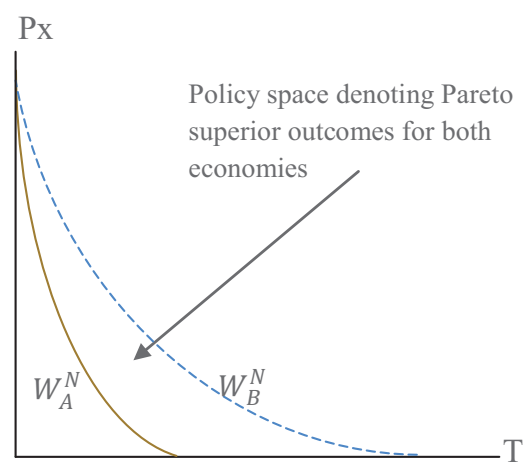

Figure 2. Necessary condition for the existence of Pareto superior policy space:

where the solid curve represents the iso-welfare locus for Economy A and the dashed curve represents the iso-welfare locus for Economy B

Hence our next step is to examine whether a sustainable cooperative equilibrium exists that is Pareto superior for both economies. With bilateral cooperation, both economies will agree to move away from unilateral policy choices. Country A will move away from the transit-rent maximizing $P_{X}$ while Economy B will agree to move away from domestic industry profit maximizing the choice of foreign input use LA and land-transit rent maximizing $\mathrm{C}$.

Let $P_{X}^{C}$ and $T^{C}$ denote the sustainable cooperative equilibrium. If an economy decides to deviate from its cooperative commitment then the other country gets to know about the deviation in the next period and punish the deviant by reverting to Nash equilibrium for all future periods. ${ }^{18}$ Under this structure, the incentive compatibility constraint (ICC) for each country

\footnotetext{
${ }^{18}$ Since the policy parameters of the two countries are additively separable in the welfare functions of the two countries, the unilateral deviation strategy for each country is identical to the Nash strategy choice (denoted by $P_{X}^{D}=P_{X}^{N}$ for country A and $T^{D}=T^{N}$ for Country B).
} 
defines the policy set that is sustainable for cooperation for each country with the gains from deviation being smaller than the cost of future punishment. Equations 3 and 4 show the ICC of the two countries.

$$
\begin{aligned}
& I C C_{A}:\left\{W_{A}^{D}\left(P_{X}^{N}, T^{C}\right)-W_{A}^{C}\left(P_{X}^{C}, T^{C}\right)\right\} \leq \frac{\rho}{1-\rho}\left\{W_{A}^{C}\left(P_{X}^{C}, T^{C}\right)-W_{A}^{N}\left(P_{X}^{N}, T^{N}\right)\right\} \\
& I C C_{B}:\left\{W_{B}^{D}\left(P_{X}^{C}, T^{N}\right)-W_{B}^{C}\left(P_{X}^{C}, T^{C}\right)\right\} \leq \frac{\rho}{1-\rho}\left\{W_{B}^{C}\left(P_{X}^{C}, T^{C}\right)-W_{B}^{N}\left(P_{X}^{N}, T^{N}\right)\right\}
\end{aligned}
$$

Equations 8 and 9 represent two equations in the two variables $P_{X}^{C}$ and $T^{C}$. In Diagram 3 the ICCs represented by the bold lines intersect at two points: one in the Nash solution denoted by E embodying the monopoly rent-seeking obstruction by the coastal neighbor and zero concession by the landlocked economy, the other in the cooperative solution denoted by F embodying lower obstruction levels by the coastal economy and positive concession offered by the landlocked economy.

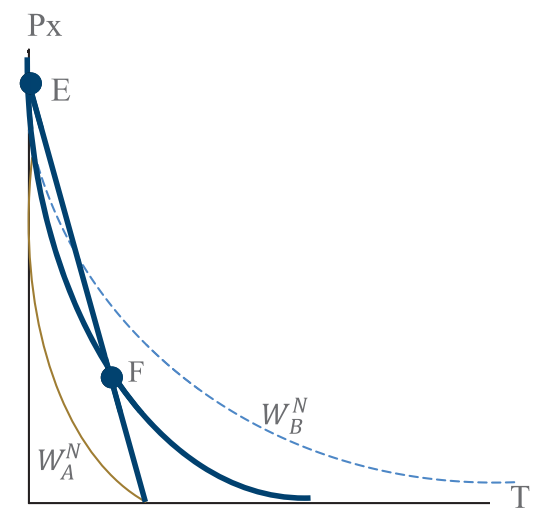

Figure 3. Cooperative and noncooperative equilibriums:

between a coastal economy and its landlocked neighbor

The cooperative equilibrium signifies Pareto superior outcome for both economies as the point $\mathrm{F}$ lies away from the origin relative to the Nash iso-welfare function for Country A and closer to the origin relative to the Nash iso-welfare function for Country B. This happens because the lowering of obstruction by the coastal economy more than compensates Economy $\mathrm{B}$ for the revenue loss caused by charging a lower price for alternate land-transit routes and also employing foreign input higher than the profit maximizing levels in the domestic industry. Similarly, the lower cost on land-routes and the additional factor income earned from B's domestic industry more than compensates A for the loss from creating a lower than monopoly-rentmaximizing obstruction to Country B for ocean access purposes. A more ambitious cooperation relative to $\mathrm{F}$, entailing even lower obstruction by $\mathrm{A}$ and even a larger concession by Country $\mathrm{B}$ is not sustainable as both economies will have an incentive to deviate when not satisfying the 
incentive compatibility criteria. The results of this section can be summarized as Proposition 1.

Proposition 1: A coastal economy would have a higher welfare by lowering the obstruction it causes to a landlocked neighbor's access to the ocean in exchange for greater employment in the domestic industry of the landlocked economy as well as offers of land-route alternatives cheaper than ocean routes for accessing other markets in the region implying that there exist self-enforcing cooperative outcomes that are Pareto superior for both the coastal and landlocked economies.

While the results are robust to meaningful parameter values of the model, a specific numerical example is helpful for a clearer understanding of the results. ${ }^{19}$

Table 1. Numerical Solutions for Noncooperation and Bilateral Cooperation between a Coastal Economy and a Landlocked Economy

\begin{tabular}{|l|l|c|}
\hline & \multicolumn{1}{|c|}{$\begin{array}{c}\text { Nash solution } \\
\left(P_{X}^{N}, T^{N}\right)\end{array}$} & $\begin{array}{c}\text { Co-operative } \\
\text { solution } \\
\left(P_{X}^{C}, T^{C}\right)\end{array}$ \\
\hline $\mathrm{T}$ & 0 & 0.069 \\
\hline $\mathrm{Px}$ & \multicolumn{1}{c|}{0.277} \\
\hline $\mathrm{W}_{\mathrm{A}}$ & \multicolumn{1}{|c|}{631.33} \\
Revenue from obstructing country B imports & $\begin{array}{l}\text { Loss from cooperation } \\
\text { Cost of land-route transit }\end{array}$ & \multicolumn{2}{|c|}{ Gain from cooperation } \\
Income from factors employed in B's domestic industry & Gain from cooperation \\
\hline $\begin{array}{l}\text { W } \\
\text { Consumer surplus from imports }\end{array}$ & $\begin{array}{l}\text { 412.75 } \\
\text { Gain from cooperation }\end{array}$ \\
Revenue from land-route transit & Loss from cooperation \\
Profits from domestic industry & Loss from cooperation \\
\hline
\end{tabular}

(Note) Parameter Values: $\alpha=10, \beta=1, m=1, n=1, C=200, N=2, \gamma=1, P y=2, \rho=0.80$

We perform several comparative stastistic analyses to test the robustness of the results. We mention two interesting exercises with real world applications. First, we find that the landlocked economy has a stronger bargaining power if it is more centrally located i.e. if it shares its borders with a larger number of countries. In this situation, its offer to provide cheap land-route alternatives to other economies of the region is more strongly valued by the coastal neighbor. While the number of neighbors and other features of the landlocked economy are predetermined, our second comparative statistic result shows that the landlocked economy can improve its bargaining power by developing its domestic industry. Every economy develops its

\footnotetext{
${ }^{19}$ The absolute magnitudes of the outcomes but not the directions of the results are dependent on the parameter values chosen for the simulation.
} 
domestic industry for the direct improvement of its welfare; however, for a landlocked economy this has a significant indirect effect. A stronger domestic industry makes the neighboring economies more interested in having a stake in the factor incomes generated in this industry, giving the landlocked country a stronger bargaining power for easier access to ocean. These results are summarized in Corollaries 1 and 2:

Corollary 1: A landlocked economy that is centrally located and can offer cheap direct land routes to other economies of the region has a stronger bargaining power and only has to offer lower concessions to its coastal neighbor in order to extract a similar reduction in obstruction to ocean access.

Corollary 2: A landlocked economy that has a well-developed domestic industry will be able to bargain for a greater reduction in obstruction to ocean access as the coastal neighbor has a vested interest in participating in the domestic industry of the landlocked economy.

As before, a specific numerical example is provided for a clearer understanding of the results.

Table 2. Numerical Solutions for Noncooperation and Bilateral Cooperation between a Coastal Economy and a Landlocked Economy

\begin{tabular}{|c|c|c|c|}
\hline & \multicolumn{3}{|c|}{$\begin{array}{c}\text { Cooperative solution } \\
\left(P_{X}^{N}, T^{N}\right)\end{array}$} \\
\hline & $\mathrm{N}=2, \gamma=1$ & $\mathrm{~N}=4, \gamma=1$ & $\mathrm{~N}=2, \gamma=2$ \\
\hline$P_{X}^{N}$ & 0 & 0 & 0 \\
\hline$T^{N}$ & 5 & 5 & 5 \\
\hline$P_{X}^{C}$ & 0.277 & 0.285 & 0.19 \\
\hline$T^{C}$ & 0.069 & 0.035 & 0.071 \\
\hline
\end{tabular}

(Note) Parameter Values: $\alpha=10, \beta=1, m=1, n=1, C=200, P y=2, \rho=0.80$

A comparison of Columns 1 and 2 of table 2 shows how the cooperative outcome changes as the landlocked economy has more neighbors. We find that while the cooperative level of obstruction (captured by $\mathrm{P}_{\mathrm{X}}$ ) by the coastal economy remains at a similar level, the necessary level of concession (captured by $\mathrm{T}$ ) by the landlocked economy is much lower if it has more neighbors. The reason is a smaller degree of concession amounts to a bigger absolute benefit to the coastal neighbor when there are more neighbors to which the landlocked economy can provide cheap access to.

A comparison of Columns 1 and 3 of table 2 shows that if the domestic industry of the landlocked economy is larger or is more productive (captured by a larger value of $\gamma$ ), the coastal 
economy is willing to make a larger reduction in the obstruction of ocean access induced by the incentive of bigger factor incomes to be earned from the landlocked economy.

\section{Conclusion}

Landlocked economies suffer from different economic constraints due to distance from major markets, dependence on coastal neighbors for ocean access, and lack of alternative transit routes resulting in a weak economy and infrastructure that is vulnerable to the policies of their neighbors. In our model of infinitely repeated games, we highlight these problems as well as explore the often overlooked strengths and policies that these landlocked economies might have at their disposal. Using the punishment mechanism of infinite reversion to noncooperative equilibrium in case of deviation by either party, we identify self-sustaining cooperative equilibrium. We show that by choosing the domestic strategies in a manner that negotiates some concessions from a country's neighbors, both a landlocked and a coastal economy would benefit from cooperation. We indicate that the unilateral obstruction policy to ocean access imposed on the landlocked countries by the coastal economies may not be optimal when viewed in the broader perspective of costs and gains involved in other markets. For the landlocked economy, our model provides lessons how, by setting the domestic policies through negotiation with the coastal neighbors, the landlocked economy might get the coastal economies to commit to a lower obstruction level, thus making the landlocked economy left less vulnerable to the policy whims of its neighboring economies.

We also demonstrate that a landlocked economy with more neighbors is in a stronger bargaining position and has to make smaller adjustments in domestic policy to achieve a similar response from a coastal neighbor. Additionally, we show that the landlocked country should put a high priority on developing its domestic industry because, in addition to direct gains, this also provides indirect leverage to negotiate larger concessions from the coastal neighbor as the stakes the coastal economy has in the landlocked economy become more valuable.

We find that the important issues of economic problems of landlocked countries have been largely unexplored in the mainstream economics literature, and our work is an important contribution in this area. The fate of landlocked economies is often viewed as predetermined, defined by its existing relation with their coastal neighbors. By modeling the unique asymmetries of the two economies in a repeated game setting, we show that bilateral cooperation between a landlocked country and its coastal neighbor offers possibilities of a coordinated change of domestic policies by both countries to improve the economic welfare of both parties.

Received 14 January 2012, Revised 25 August 2012, Accepted 05 November 2012 


\section{References}

Ahmed, Sadiq and Ghani Ejaz, 2008. "Making Regional Cooperation work for South Asia's Poor", Policy Research Working Paper Series 4736, The World Bank.

Arvis, Jean-Franois, Gael Raballand and Jean-Francois Marteau (2010): "The Cost of Being Landlocked: Logistics Costs and Supply Chain Reliability", Series: Directions in development, Trade, Publisher: World Bank, Washington, D.C.,

Borchert, Ingo, Batshur Gootiiz, Arti Grover and Aaditya Mattoo, "Landlocked or Policy Locked? How Services Trade Protection Deepens Economic Isolation”, Policy Research Working Paper Series 5942, The World Bank.

De, Prabir (2006): "Trade, Infrastructure and Transaction Costs: The Imperatives for Asian Economic Cooperation", Journal of Economic Integration, 21(4), pp. 708-735

Debrie J and B. Steck, (2001): "L'enclavement, reevaluation theorique et application a l'Afrique de l'Ouest", L'espace geographique 30(1), pp: 26-36

Faye Michael L, John W Macarthur, Jeffery D Sachs and Thomas Snow (2004): "The challenges facing landlocked developing countries", Journal of Human Development, 5(1), pp: 31-68

Grigoriou, Christopher, 2007. "Landlockedness, infrastructure and trade : new estimates for central Asian countries," Policy Research Working Paper Series 4335, The World Bank.

Jayaraman T.K, Shrestha O. L, (1976): "Some Trade Problems of Land Locked Nepal”, Asian Survey, 16(12), pp: 1113-1123.

MacKellar, Landis, Andreas Worgotter and JuliaWorz (2000): "Economic Development problems of landlocked countries", Transition Economic Series No.14.

Raballand Gael, (2003): "Determinants of the negative Impact of being landlocked on Trade: An Empirical Investigation through the Central Asian case", Comparative Economic Studies, Vol. 45, pp: 520-536.

Radelet, Steven and Jeffrey D. Sachs "Shipping Costs, Manufactured Exports, and Economic Growth", Presented at the Annual Meeting of the American Economics Association, Chicago, January 3-5, 1998.

Shrestha Hemanta K and Heffley Dennis 2003, "Regional Integration and Industrial Location in a landlocked Spatial Economy", Department of Economics working paper, University of Connecticut.

Shrestha, Hemanta K. and Mukti P. Upadhyay (2004): "Political Economy of Regional Trading Arrangements in South Asia", Journal of Economic Integration, 19(3), pp. 427-446 